\title{
I mpact of applying hygienic practices at farm on bacteriological quality of raw milk
}

\author{
N. Pandey, A. Kumari, A. K. Varma, S. Sahu and M. A. Akbar
}

\begin{abstract}
Department of Livestock Production Management, Buffalo Research Centre, College of Veterinary Science, Lala Lajpat Rai University of Veterinary and Animal Science, Hisar - 125 004, Haryana, India.

Corresponding author: S. Sahu, e-mail: subhasishsahu72@gmail.com, NP: siya97singh@gmail.com, AK: anujsrkumari@gmail.com, AKV: akvarma1954@gmail.com, MAA: drma.akbar@gmail.com

Received: 11-06-2014, Revised: 13-08-2014, Accepted: 22-08-2014, Published Online: 30-09-2014
\end{abstract}

doi: 10.14202/vetworld.2014.754-758. How to cite this article: Pandey N, Kumari A, Varma AK, Sahu S, Akbar MA (2014) I mpact of applying hygienic practices at farm on bacteriological quality of raw milk, Veterinary World 7(9): 754-758.

\begin{abstract}
Aim: The present study was carried out to explore the potential source of contamination and the efficacy of different washing practices towards quality milk production.

Materials and Methods: Probable sources of contamination viz. stored water, potable water, milker's hands, milking pail, udder of individual buffalo and milk cans were subjected to different types of bacterial counts before the actual experiment to start. Twenty milch buffaloes thereafter were divided randomly into four treatment groups where washing was performed in each step viz. milker hands, udder of individual buffalo, milking pail and milk cans before milking either with water $\left(\mathrm{T}_{0}\right.$ : stored water, $\mathrm{T}_{1}$ : potable water) or sanitizers $\left(\mathrm{T}_{2}: 200 \mathrm{ppm}\right.$ chlorine solution, $\mathrm{T}_{3}: 50 \mathrm{ppm}$ iodophore solution) for 60 days. Bacterial counts again were performed for last 5 alternate days for all the sources involved along with the microbial load of raw milk. Data obtained were subjected to standard statistical analysis.

Results: It was found that for all bacterial count stored water contributed significantly higher as compared to the potable water. Among the other potential sources of contamination $\left(\log / 6 \mathrm{~cm}^{2}\right)$, standard plate count (SPC) and coliform count were significantly highest for milking pail (6.73 \pm 0.02$)$ and udder of milch buffaloes (3.77 \pm 0.12$)$, respectively, while for Staphylococci count both milking pail $(3.24 \pm 0.02)$ and milking can $(3.22 \pm 0.04)$ were contributed maximally $(p<0.05)$ than others. Washing with stored water contributed significantly $(\mathrm{p}<0.05)$ more microbial load from all possible sources of contamination and too reflected on milk quality (SPC: $7.87 \pm 0.04$, coliform: $4.06 \pm 0.46$ and Staphylococci: $3.41 \pm 0.01$ ) than the other washing treatments, which are followed by washing with potable water. Both the sanitizers were significantly better than the washing with the water but remained statistically similar ( $p>0.05)$ for most of the parameters, even for the raw milk quality.
\end{abstract}

Conclusion: Study revealed that milker hands, milking pails, udder of animals, milk cans and stored water used for washing of equipment are the potential source of contamination in raw milk. These were counted as critical point which needs attention for the production of high-quality milk. Potable water was found to be better than stored water. The use of either chlorine 200 ppm and iodophor 50 ppm is highly effective in reducing the bacterial population for quality milk production.

Keywords: milk, sanitizer, source of contamination, washing, water.

\section{I ntroduction}

Milk taken from healthy udder is often free of pathogens germs in addition it is pure, clean, safe, sound, and wholesome. However due to its high nutritive value and high moisture content, raw milk serves a good medium also for microbial growth that degrades the milk quality and shelf-life of milk. Hence, many dairy programs have been carried out to improve the production as well as quality of raw milk [1]. Contamination of milk and milk products with pathogenic bacteria is largely due to processing, handling, and unhygienic conditions [2]. Bacterial contamination of raw milk can originate from different sources: Air, milking equipment, feed, soil, feces and grass [3]. Rinsing water for milking machine and milking equipment washing also involve some of the reasons for the presence of a higher number of micro-organisms,

Copyright: The authors. This article is an open access article licensed under the terms of the Creative Commons Attributin License (http: // creative commons.org/licenses/by/2.0) which permits unrestricted use, distribution and reproduction in any medium, provided the work is properly cited. including pathogens in raw milk [4,5]. Categorized the milk having standard plate count (SPC) $<2,00,000$ as very good; 200,001-1,000,000 as good, 1,000,000 to $5,000,000$ as fair and $>5,000,000$ as poor. The quality status in Western Countries is more stringent, as milk with SPC of 100,000 is not accepted for processing. A systemic application of descriptive food safety work is one of the most important tools for meeting these standards, if it is implemented from farm to consumers.

Cleaning and disinfection are, therefore, need to be addressed in every hazard analysis critical control point plan [6]. The first critical control point to be identified when the cleaning solution is prepared is the concentration. A too low concentration will result in insufficient cleaning and will have an additional negative impact on the disinfection step afterwards [6].

The present study was conducted to know the efficacy of washing practices on microbial load from possible sources of contamination and on raw milk for quality milk production. 


\section{Materials and Methods}

\section{Ethical approval}

Approval was taken from research committee and Institutional Animal Ethical Committee of Lala lajpat Rai University of Veterinary and Animal Sciences, Hisar. Collection of milk sample was done by following standard operating procedure.

\section{Experiment site}

The study was conducted on 20 healthy milch buffaloes between second and fourth parity in the Department of Livestock Production and Management, Lala Lajpat Rai University of Veterinary and Animal Sciences (LUVAS), Hisar during the month of February-April. These buffaloes were divided randomly into four treatment groups where washing was performed in each step viz. milker hands, udder of individual buffalo milking pail and milk cans before milking either with water or sanitizer and represented as $\mathrm{T}_{0}$ (stored water), $\mathrm{T}_{1}$ (potable water), $\mathrm{T}_{2}$ (200 ppm chlorine solution) and $\mathrm{T}_{3}$ (50 ppm iodophore solution) with five buffalo in each.

At the beginning of the experiment all the probable sources of contamination viz. stored water $(n=4)$, potable water $(n=4)$, milker's hands $(n=4)$, milking pail $(n=20)$, udder of individual buffalo $(n=20)$ and milk cans $(n=4)$ were subjected to SPC and different types of bacterial counts viz. Coliform, Staphylococci count. Water sample from two different sources i.e., stored (in underground cemented tank) and potable (fresh running) water, were collected in sterile bottles with four replications in each for 5 alternate days. $1 \mathrm{ml}$ representative sample from each bottle was serially diluted to quantify the different bacteria of interest. For the rest of the sources, swab was taken from approximately $6 \mathrm{~cm}^{2}$ surface areas each from milker's hands, milking pail, udder of individual buffalo and milk cans for 5 alternate days. Procedure of swabbing is discussed in the later part.

Each treatment group was thereafter subjected to different washings for 60 days, and the bacterial counts again were performed for last 5 alternate days for all the sources involved prior to milking viz. Milker's hands, udder, milking pail, and milk cans. Raw milk was collected by sterile bottle from each milking pail immediately after milking for the same duration as above and serial dilution were made as like bacterial count of water mentioned earlier to know the effect of applying hygienic practices on bacteriological quality of milk.

\section{Swabbing and different bacterial count}

The surfaces were swabbed with cotton-tipped swab. First of all autoclaved swab were inserted into $10 \mathrm{ml}$ of sterile water tube for moistening. Before swabbing, the swab head was pressed against the interior wall of the tube to remove excess water. It was slowly and thoroughly rubbed over approximately $6 \mathrm{~cm}^{2}$ surfaces of milker hands, milking pail, udder of individual buffalo, and milk cans. Each swab sample was analyzed for SPC, Staphylococci count and coliform count by using media namely plate count agar media, Staphylococci medium 110 and violet red bile agar medium, respectively. All plates were incubated at $35^{\circ} \mathrm{C}$ for $24-48 \mathrm{~h}$.

\section{Statistical analysis}

Statistical analysis was based on parametric test, and all the treatment groups were analyzed using one-way analysis of variance (ANOVA). The mean of various treatments were compared as described by earlier scientists [7].

\section{Results and Discussion}

Significantly higher $(\mathrm{p}<0.05)$ bacterial count (all types) were found from stored water than potable water (Table-1). The potable water is of better quality when compared to stored water that is commonly used for washing of milking pail/can, milker's hand and udder of buffalo. Similarly, it was identified that using contaminated or poor quality water for personal hygiene, cleaning utensils and animals can be another means of milk contamination with Escherichia coli [8] and lack of proper water for washing milk equipment and animal and ignorance of hygienic practices may be the possible reasons for high contamination of Staphylococcus aureus $[9,10]$. It is evident that (Table-1) milker hand, udder of animals, milking pail and milk can all act as potential source of contamination for milk [11]. There is significant difference $(p<0.05)$ between all the sources for SPC. It was highest in milking pail and milk can, followed by udder and milker hand. Milking equipment may play a significant role in the contamination of milk with this microorganism, mainly during milking, by means of direct contact between milk and the surfaces of contaminated equipment [12] and various utensils such as plastic buckets and bulk storage tanks used during milk collection usually constitute the source of greatest contamination of milk [13]. However in case of coliform and Staphlococci count between milking

Table-1: Bacterial count of different potential sources of contamination.

\begin{tabular}{lccc}
\hline Source & SPC & Coliform & Staphylococci \\
\hline $\begin{array}{l}\text { Stored } \\
\text { water log/ml }\end{array}$ & $3.49^{\mathrm{b}} \pm 0.01$ & $2.53^{\mathrm{b}} \pm 0.01$ & $1.45^{\mathrm{b}} \pm 0.03$ \\
$\begin{array}{l}\text { Potable } \\
\text { water log/ml }\end{array}$ & $0.77^{\mathrm{a}} \pm 0.01$ & $0.05^{\mathrm{a}} \pm 0.00$ & $0.00^{\mathrm{a}} \pm 0.00$ \\
$\begin{array}{l}\text { Milkers hand } \\
\text { log/ } 6 \mathrm{~cm}^{2}\end{array}$ & $5.51^{\mathrm{c}} \pm 0.02$ & $3.24^{\mathrm{c}} \pm 0.17$ & $2.71^{\mathrm{c}} \pm 0.07$ \\
$\begin{array}{l}\text { Udder log/ } 6 \mathrm{~cm}^{2} \\
\text { Milking pails }\end{array}$ & $6.62^{\mathrm{d}} \pm 0.01$ & $3.77^{\mathrm{d}} \pm 0.12$ & $2.95^{\mathrm{d}} \pm 0.02$ \\
$\begin{array}{l}\text { log/ } 6 \mathrm{~cm}^{2} \\
\text { Milk can }\end{array}$ & $6.64^{\mathrm{d}} \pm 0.02$ & $3.38^{\mathrm{c}} \pm 0.15$ & $3.24^{\mathrm{e}} \pm 0.02$ \\
log/6 cm & $3.32^{\mathrm{c}} \pm 0.13$ & $3.22^{\mathrm{e}} \pm 0.04$ \\
$\mathrm{CD}$ & 0.05 & 0.35 & 0.12 \\
\hline
\end{tabular}

Mean with different superscript in a row differ significantly $(p<0.05) . S P C=$ Standard plate count, $C D=$ Critical difference 
pail and milking cans significant difference was not observed, whereas all other source observations were not differed significantly $(\mathrm{p}<0.05)$.

Unwashed milker hand play an important role to add bacteria (Table-1) and the mean value of bacterial count after washing with potable water and sanitizer (Table-2) shows that the highest count was observed under control $\left(\mathrm{T}_{0}\right)$, followed by $\mathrm{T}_{1}, \mathrm{~T}_{2}$ and $\mathrm{T}_{3}$. The average value of all bacterial count had a significant $(\mathrm{p}<0.05)$ difference between control and potable water. Regarding the $\mathrm{T}_{2}$ and $\mathrm{T}_{3}$ difference was not significant. The milk can be contaminated by $S$. aureus when there is an infection of the mammary gland or bad hygiene during handing and processing, such as not washing hands when handling milk [14]. The application of personal hygiene such as when the milker rubbed his hands with clean wet towels before milking and when the milker washed his hands with soap and water, put on a clean coat, covered his hair, there was a significant effect of application of hygienic practices on total bacterial count, S. aureus count and coliform count $(p<0.01)$. The bacterial load noticeably reduced when above treatment was applied [15]. Milk come in direct contact with pail surface. Hence cleaning and disinfection are very important in hygienic milk production. The SPC was found to be highest in case of control $\left(6.64 \log / 6 \mathrm{~cm}^{2}\right)$ and lowest in pail treated with $50 \mathrm{ppm}$ of Iodophore solution $\left(2.67 \mathrm{log} / 6 \mathrm{~cm}^{2}\right)$. There is no significant difference $(p>0.05)$ between treatments $T_{2}$ and $T_{3}$ in all type of bacterial count, but a significant difference between the treatments $\mathrm{T}_{0}$ and $\mathrm{T}_{1}$ in SPC and Staphylococci while coliform count shows no significant difference between treatments. Similarly, it was reported that improperly cleaned milking pail is the potential source of bacterial contamination, use of chlorine solution improved bacterial quality of milk by manifold [16].

Udder and teat surface are the major source of contamination (Table-1). The mean average bacterial count for all types of bacteria was significantly higher $(\mathrm{p}<0.05)$ in the control group $\left(\mathrm{T}_{0}\right)$ as compared to $\mathrm{T}_{1}$. However, there was no significant difference $(\mathrm{p}>0.05)$ in bacterial count in case of SPC and Staphylococci count between $\mathrm{T}_{2}$ and $\mathrm{T}_{3}$, but significant $(\mathrm{p}<0.05)$ difference was observed in coliform count between $\mathrm{T}_{2}$ and $\mathrm{T}_{3}$, thereby showing Iodophore treatment to be superior to that of chlorine in reducing the coliform count (Table-2). The cleaning of udder with $0.5 \%$ iodophore solution reduced the bacterial load of milk when compared to washing the udder only with water only [17]. Similar observations were reported by other [18].

The use of potable water significantly $(\mathrm{p}<0.05)$ reduces SPC, coliform and Staphylococci count. Washing of milk can with chlorine and iodophore solution further reduced the all types of bacterial count many folds (Table-2). It was further observed

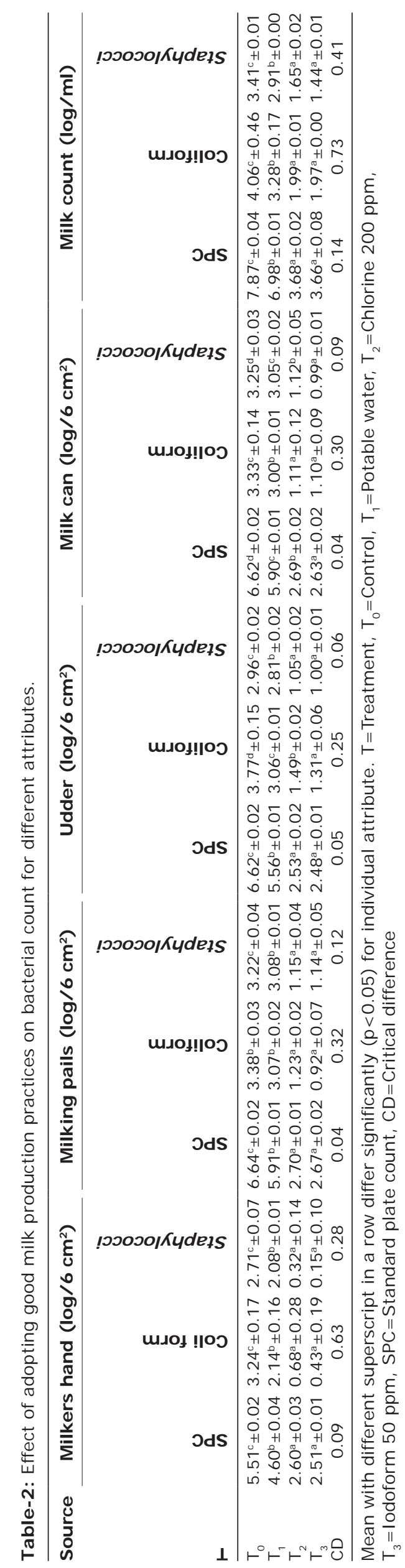


that iodophore solution was significantly $(\mathrm{p}<0.05)$ more effective than chlorine solution in a reduction of SPC and Staphylococci count, while decrease in coliform count was found non-significant between $\mathrm{T}_{2}$ and $\mathrm{T}_{3}$. Similarly, it was found that bacterial count in washed and unwashed can be $3.8 \times 10^{5}$ and $5.0 \times 10^{6}[19]$.

The milker hand, milking pail, udder of animals and milk can were a potential source of contamination (Table-1). If the load of bacteria in these sources becomes higher than the bacterial count of milk also increases automatically. The highest SPC, coliform and Staphylococci count in milk in control $\left(\mathrm{T}_{0}\right)$ followed by washing with potable water $\left(T_{1}\right)$, chlorine solution and iodophore solution $\left(T_{3}\right)$, respectively. There was a significant $(\mathrm{p}<0.05)$ difference between control and potable water for all types of bacterial count studied. On the contrary, no significant difference was observed between $T_{2}$ and $T_{3}$ for all bacterial count. The personal hygiene of farmers and unhygienic utensils used during the milking process contributed most to the bacteriology quality of raw milk. A significant reduction on microbial count of milk was observed after the hygienic practices were introduced by the dairy farmers [20]. It was reported that reported that milk produced under hygienic condition always expected to have low bacterial count [21]. The anaerobic and aerobic bacterial reduced even by a simple rinse of milk can with potable water [19].

\section{Conclusions}

It is inferred that milker hands, milking pails, udder of animals, milk cans and stored water used for washing of equipment are the potential source of contamination in raw milk. These were counted as critical point, which needs attention for the production of high-quality milk. Potable water was found to be better than stored water. The use of either chlorine $200 \mathrm{ppm}$ and iodophor $50 \mathrm{ppm}$ is highly effective in reducing the bacterial population to desired level and increasing the shelf life of milk.

\section{Authors' Contributions}

AKV and MAA planned and designed the experiment, NP performed the experiment and all tests, AK and SS drafted and revised the manuscript. All authors read and approved the final manuscript.

\section{Acknowledgments}

The authors are thankful to the Dean Post Graduate Studies and honorable Vice Chancellor of LUVAS, Hisar for providing necessary funds and facilities to carry out research.

\section{Competing I nterests}

The authors declare that they have no competing interests.

\section{References}

1. Bonfoh, B., Roth, C., Traore, A.N., Fane, A., Simbe C.F. and Alfaroukh, I.O. (2006) Effect of washing and disinfecting containers on the microbiological quality of fresh milk sold in Barnako (Mali). Food Control, 17(2): 153-161.

2. Maity, T.K., Kumar, R. and Misra, A.K. (2010) Prevalence of enteropathogenic Escherichia coli isolated from chhana based Indian sweets in relation to public health. Indian $J$. Microbiol., 50(4): 463-467.

3. Coorevits, A., De Jonghe, V., Vandroemme, J., Reekmans, R., Heyrman, J., Messens, W., De Vos, P. and Heyndrickx, M. (2008) Comparative analysis of the diversity of aerobic-spore-forming bacteria in raw milk from organic and conventional dairy farms system. Syst. Appl. Microbiol., 31(2): 126-140.

4. Bramley, A.J. and McKinnon, C.H. (1990) The microbiology of raw milk. In: Robinson, R.K. editor. Dairy Microbiology. I. Elsevier Applied Science, London, New York. p. 171.

5. BIS. (1986) Bureau of Indian Standard. Microbiological Quality of Dairy Product Part-ll. A Compendium on Micribiology Specification. Manak Bhavan, New Delhi.

6. Sande, C.A.F.M., Smeulders, C.N.M. and Van Der. (1997) The impact of HACCP on cleaning and disinfection. In: World Congress on Food Hygiene. Hague, The Netherlands; 26 August.

7. Snedecor, G.W. and Cochran, W.G. (1994) Statistical Methode. $8^{\text {th }}$ ed. Oxford and IBH Publishing Co., New Delhi.

8. Mai, H.M., Irons, P.C., Junaidu, K. and Thompson, P.N. (2012) A large seroprevalence survey of brucellosis in cattle herds under diverse production systems in Northern Nigeria. Bio. Med. Central Vet. Res., 8(144): 1-14.

9. Iyer, R., Anand, S.K. and Dang, K.A. (2010) Incidence of microbiological hazards in organized and peri urban dairy farm and single animal holdings in tropical environment. Res. J. Dairy. Sci., 4(3): 23-27.

10. Srinu, B., Kumar, A.V., Kumar, M.S., Narayana, B.V.L. and Rao, T.M. (2012) Assessment of microbiological quality and associated health risks of raw milk sold in and around Hyderabad City. Int. J. Pharm. Biol. Sci., 3(4): 609-614.

11. Kim, J.W. (1996) Studies on bacteriological condition in the milking environment. Korean J. Dairy Sci., 17: 113-122.

12. Fagundes, H., Corassin, C.H., Tavolaro, P. and Oliveira, C.A.F. (2012) Milk hygienic practices and occurrence of Staphylococcus aureus and Escherichia coli O157:H7 in small-scale dairy farms in Sao Paulo. Afr. $J$. Microbiol. Res., 6(28): 5805-5808.

13. Millogo, V., Sjaunja, K.S., Ouedrago, G.A. and Agenas, S. (2010) Raw milk hygiene at farms, processing units and local markets in Burkina. Faso. Food Control, 21(7): 1070-1074.

14. Donkor, E.S., Aning, K.G., Omore, A., Nurah, G.K., Osafo, E.L.K. and Staa, S. (2007) Risk factors in the hygienic quality of milk in Ghana. Food Sci. J., 1: 6-9.

15. Mohamed, O.M.A, and Fatima, M.M.E. (2011) The impact of applying some hygienic practices on raw milk quality in Khartoum State, Sudan. Res. J. Agric. Biol. Sci., 7(2): 169-173.

16. Rajorhia, G.S. (2001) Quality management during production and procurement of milk. Proceeding of Total Quality Management in Dairy Processing, Held at National Dairy Research Institute, Karnal, March 1-30.

17. Ingawa, K.H., Adkinson, R.W, and Gough, R.H. (1992) Effect of a gel teat cleaning and sanitizing agent on milk quality and udder health. J. Dairy Sci., 74 (Suppl 1): 204.

18. Sahota, R.S. and Saini, A.L. (2001) Hygienic practices during milking and handling thereafter. Proceeding of the National Seminar on Quality Assurance in Dairy Industry held at Punjab Agricultural University, Ludhiana from Sept, 8-9, 2001. Indian Dairy Association, New Delhi.

19. Siva, C.V, and Sannaphadts, S. (1994) Dung and milk cans 
as source of aerobic and anaerobic bacterial spore contamination of raw milk. Indian J. Dairy Sci., 47: 401-405.

20. Yuen, S.K., Yee, C.F, and Yin, F.H. (2012) Microbiological quality and the impact of hygienic practices on the raw milk obtained from the small-scale dairy farmers in sabah,
Malaysia. Int. J. Agric. Food Sci., 2(2): 55-59.

21. Sanua, M., Poutrel, B., Monard, J.L. and Seneys, F. (1993) Risk factor associated with contamination of raw milk by Listeria monocytogenes in dairy farm. J. Dairy Sci., 76: 2891-2898.

$* * * * * * * *$ 